\title{
Innovation Implementation by SMEs in Trinidad and Tobago
}

\author{
Priscilla Bahaw, PhD \\ Lecturer at The University of the West Indies, Trinidad and Tobago
}

doi: 10.19044/esj.2017.v13n10p186 URL:http://dx.doi.org/10.19044/esj.2017.v13n10p186

\begin{abstract}
Innovation has become an important contributing factor to firms' competitive advantage. However, little research has been carried out in understanding innovation in small and medium-sized enterprises in the English-speaking Caribbean countries, particularly in Trinidad and Tobago. This study evaluates the degree to which small and medium-sized enterprises in Trinidad and Tobago engage in innovative activities within their businesses' operations and identifies the major barriers to innovation that are experienced by these firms.

This exploratory study utilized primary data collected through delivery and collection survey questionnaires from 350 randomly selected small and medium-sized enterprises with a minimum active operation period of five years in Trinidad and Tobago. The questionnaire, administered to the longest serving employees of the small and medium-sized enterprises, was designed to collect information on each small and medium-sized enterprise about their innovation experiences, the innovative environment, and innovation barriers. Some of the variables measured were adapted from the Community Innovation Survey found in previous research done by Sileshi Talegeta (2014).

The key findings from the research revealed that there are limited efforts of small and medium-sized enterprises in Trinidad and Tobago to implement strategies for encouraging innovation within their organizations. More specifically, it was found that there are low levels of product innovation, process innovation, marketing innovation, and organizational innovation in small and medium-sized enterprises in Trinidad and Tobago. The data suggested that the main barriers to innovation present in small and mediumsized enterprises in descending order of intensity are as follows: organizational culture, lack of reward and recognition, lack of finance, lack of skilled personnel, and lack of knowledge, lack of co-operation, market barriers, and legal barriers. The conclusion from the research findings
\end{abstract}


showed that internal and external factors hindered the small and mediumsized enterprises in Trinidad and Tobago innovation capabilities.

Keywords: Innovation, barriers, small and medium sized enterprises, competitive advantage, Trinidad and Tobago

\section{Introduction}

Small and medium-sized enterprises contribute significantly to economic development. In Trinidad and Tobago, small and medium-sized enterprises contribute twenty-eight percent to the country's gross domestic product, account for ninety-one percent of all registered businesses and employ approximately 200,000 persons in the country (Schwab, 2013).

The driving force behind these small and medium-sized enterprises is entrepreneurship, which, identified by Kuratko (2014), is a process of vision, change and creation that requires energy application and passion to create. Innovation is of critical importance to businesses survival and growth and is central to gaining competitive advantage due to growing trends in technology and international trade. However, fostering innovation is not simple. It requires a unique mix of strategies to reduce the obstacles that can prevent the implementation of innovation.

As stated by Talegeta (2014), 'Innovation is regarded as the most important competitive advantage that enables a company to thrive in today's dynamic business environment'. Though innovation is recognized as important, its enhancement is challenging. According to Bailey, Pacheco, Carillo, Pememberton, and Ghany (2015), Trinidad and Tobago lacked innovation. Trinidad and Tobago's ranking in the Global Competitiveness Index 2013 to 2014 fell from eighty-fourth to ninety-second out of 148 countries in its innovative capacity (Bailey et al., 2013). Trinidad and Tobago ranked lowest in the provision of novelty products to consumers and there was a deficiency in innovative products offerings by Trinidad and Tobago early-stage entrepreneurs.

\section{Rationale for Study}

Extensive academic research has concentrated only on exploring four broad issues: types of innovation, strategies used to foster innovation, innovation challenges, and levels of innovation in firms. However, much less research has investigated the levels of innovation within the major classifications. Additionally, the empirical literature on innovation barriers is extensive, but limited to a few countries including Nigeria, European Union countries and Indonesia, among others. Little research has been carried out in understanding small and medium-sized enterprises innovation challenges in the English-speaking Caribbean countries, particularly in Trinidad and 
Tobago. Consequently, the literature lacks theoretical studies on the extent to which the existing conceptual frameworks on innovation types and barriers extend to small and medium-sized enterprises in Trinidad and Tobago.

\section{Research Objectives}

The purpose of this paper is to contribute to the theoretical understanding of the types of innovation and major challenges to innovation experienced by small and medium-sized enterprises in Trinidad and Tobago. More specifically, this research is aimed at addressing the gap between levels of innovation and classifications of innovation. The findings of this research are expected to increase practitioners' awareness of the factors that can hinder innovation which have implications on their businesses performance and competitive edge. The research questions driving this study are as follows:

- $\quad$ To what extent are the types of innovation frequently practiced by small and medium-sized enterprises in Trinidad and Tobago?

- What are the main barriers to innovation that are experienced by small and medium-sized enterprises in Trinidad and Tobago?

\section{Literature Review}

Entrepreneurship is responsible for the conception of new organizations, products, services, jobs, and opportunities for corresponding economic activities (Markatou \& Stournaras, 2013). Kuratko (2014) described entrepreneurship as a dynamic process of vision, change, and direction. It requires an application of energy and passion towards the creation and implementation of new ideas and creative solutions. From this definition, the linkage between entrepreneurship to creativity and innovation can be recognized. Early work referred to innovation as a function of entrepreneurship (Drucker, 1985) where it is the process of the adoption of internally or externally generated devices, systems, policies, programs, processes, products, or services that are new to the adopting organization (Damanpour, 1991). The Organization for Economic Cooperation and Development (2005) described innovation as all scientific, technological, organizational, financial and commercial activities which lead to the implementation of new or improved products. Sousa (2006) contended that innovation can be defined as the result of activities that use knowledge to create new value to those benefiting from its use. Regardless of the variations on the definitions for innovation, researchers consistently admitted that innovation is important to firms. Kim and Maubourgne (2005) suggested that innovation is needed to survive and thrive in hyper-competitive markets. Similarly, Horth and Buchner (2014) stated that competitive trends in the business environments require leaders to create a climate for innovation in 
organizations with the essential innovative systems, tools, and thinking which are critical for the health and future viability of the business. Failure to innovate and transform can lead firms into the decline stage (Chand, 2015).

\section{Forms of Innovation}

Schumpeter (1934), recognized as a pioneer in the innovation literature, categorized innovation as the introduction of a new good or a new quality of the good, the introduction of a new method of production, the opening of a new market, the conquest of a new source of supply, and the carrying out of the new organization of an industry.

Mbizi et al. (2013) considered innovation as three main dimensions which include:

- $\quad$ Radically re-conceiving products and services, not just developing new products and services

- $\quad$ Redefining market space

- $\quad$ Redrawing industry boundaries

A more recent theoretical perspective, Talegeta (2014), specified that there are four general types of innovations which can occur in an organisation which are:

1) Product innovation: is the introduction of a good or service that is new or significantly improved with respect to its characteristics or intended uses.

2) Process innovation: is the implementation of a new or significantly improved production and/or delivery method for the creation and provision of services.

3) Marketing innovation is the implementation of a new marketing method involving significant changes in product design or packaging, product placement, product promotion and pricing that is use of new pricing strategies to market,

4) Organizational innovation is the implementation of a new organizational method in the firm's business practices, workplace organization or external relations.

\section{The importance of innovation to firms:}

Several early studies acknowledged that innovation can contribute to the positive financial performance of firms (Covin \& Slevin, 1989; Dess et al., 1997; Lumpkin \& Dess, 2001; Wiklund \& Shepherd, 2005). Han et al. (1998) and Lewis (1993) agree business success requires continuous improvement and innovation. Serrat (2009) claimed that innovation is considered critical for organisational survival. As stated by Zemplinerova (2010), the investments on research, development, and introduction of innovations are the determining characteristics for gaining a dominant part of 
the market. More comprehensively, a later study done by DeAngelis (2012) stated that when an entrepreneur develops and nurtures an innovative environment, the earnings can be plentiful. Babu, Krishna and Swathi (2013) emphasised that successful entrepreneurs require an edge derived from some combination of a creative idea and a superior capacity for execution. Martin-de Castro et al. (2013) stated that developing innovations is essential for creating and sustaining an organisation's competitive advantage. Deshati (2016) found that innovation is an important element to increase profits and market shares in businesses. The table below represents the importance of innovation which is integral in achieving a sustainable competitive advantage (Tidd et al., 2007).

Table 1: Importance of innovation to firms' competitive advantage

\begin{tabular}{|c|c|}
\hline $\begin{array}{c}\text { Categories of innovation } \\
\text { importance }\end{array}$ & Details \\
\hline Growth & $\begin{array}{c}\text { Given competition, growth can be achieved also by means of } \\
\text { non-price factors such as design, quality and individualisation }\end{array}$ \\
\hline Demand and Market & $\begin{array}{c}\text { A strong positive relationship between market performance } \\
\text { and new products. } \\
\text { New products help maintain market shares and improve } \\
\text { profitability. }\end{array}$ \\
\hline Efficiency & $\begin{array}{c}\text { Innovation of processes that lead to production time } \\
\text { shortening and speed up new product development in } \\
\text { comparison to competitors }\end{array}$ \\
\hline Product Life Cycle & Ability to substitute outdated products that has shortening \\
product lifecycles.
\end{tabular}

Source: developed from Tidd et al. (2007)

\section{Classifying firms by degree of innovativeness}

Fitjar and Rodriguez-Pose (2013) further classified firms into various degrees of innovativeness and novelty which are:

- Incremental innovation: makes a small change to an existing process or product

- $\quad$ Radical innovation: introduces a drastic change to the production process contributing to a different genre of innovative products

- $\quad$ New to the firm: the product of process may already exist in other firms but if it is introduced to a firm for the first time, then it will be considered a level of innovation

- $\quad$ New to the market: a product or process may already exist but if introduced in a new market which had no prior exposure to the product or process, it is considered a level of innovation 


\section{Barriers to innovation}

Schwab (2013) recognized innovation as one of the twelve pillars of competitiveness. Schwab (2013) further recognised in the 2012 Global Entrepreneurship Monitor Trinidad and Tobago Report that Trinidad and Tobago lacked innovation. Trinidad and Tobago's innovative capacity ranking in the World Economic Forum’s Global Competitiveness Index 2013 to 2014 fell from eighty-fourth to ninety-second place out of 148 countries (Schwab, 2013). Among the countries reviewed in the Caribbean region and throughout the Americas, Trinidad and Tobago was ranked the lowest in terms of the provision of novelty products to consumers and there was a clear deficiency in the innovative nature of product offerings by Trinidad and Tobago early-stage entrepreneurs

There are many challenges preventing small and medium-sized enterprises from being innovative. Tidd et al. (2007) viewed innovation as a challenge but stated that organisations need to renew their products and processes regularly as their survival chances are threatened. Previous research disclosed that the barriers to innovation were related to cost, institutional constraints, human resources, organizational culture, flow of information, government policy, lack of finance, high economic risk, lack of skilled personnel, lack of information about technology and market, lack of customer responsiveness, and government regulations (Baldwin \& Lin, 2002; Mohen \& Roller, 2005; Silva et al., 2007; Lim \& Shyamala, 2007). Similarly, small and medium-sized enterprises around the world have experienced comparable barriers to innovation, including a lack of available finance, infrastructure, skilled knowledge workers, and regulations (OECD, 2005). Small and medium- sized enterprises in less developed countries face further barriers including lack of technological and policy infrastructure, bad location and inappropriate firm size for the market (Demirbas, 2011).

Assink (2006) defined four categories of barriers to innovation within businesses:

1) Adoption barriers: related to dominant designs, path dependency and successful products limit the ability to search for new disruptive innovations.

2) Mindset barriers: related to the inability to unlearn the old logic of how products and markets work.

3) Risk barriers: associated with an excessive reliance on routines and experience and an unwillingness to cannibalise the own product markets. Disruptive innovations often threaten the existing products of established firms.

4) Nascent barriers: associated with management capabilities to foster thinking out of the box and the management of the innovation process.

Talgeta (2014) identified several barriers to innovation which any organisation can experience. These are displayed in table 2 below. 
Table 2: Barriers to innovation

\begin{tabular}{|c|}
\hline Barriers to innovation \\
\hline High Cost of Innovation (HCI) \\
\hline Lack of Finance (LF) \\
\hline Government Policy and Regulation (GPR) \\
\hline Organizational Culture (OC) \\
\hline Lack of Skilled Personnel (LSP) \\
\hline Size of enterprise (SE) \\
\hline Inadequate Research and Development (IRD) \\
\hline Lack of Cooperation (LC) \\
\hline Lack of Technological and Market Information (LTMI) \\
\hline
\end{tabular}

Source: Talgeta (2014)

While internal barriers to innovation are primarily an issue of management, organization and firm competences, external barriers emerge when the firm interacts with other firms, agents or institutions.

The community innovation survey (CIS) contained nine different potential barriers to innovation. In this study, we have considered five different barriers to innovation (in brackets the original wording from the CIS questionnaire):

(i) Financial barriers to innovation (Lack of finance from sources outside your enterprise),

(ii) Skill barriers to innovation (Lack of qualified personnel),

(iii) Lack of information on technology,

(iv) Lack of information on markets, and

(v) Lack of innovation partners (Difficulty in finding cooperation partners for innovation).

\section{Research Methodology}

The purpose of this study is to examine how innovative are small and medium-enterprises in Trinidad and Tobago and to identify the major challenges to innovation that are experienced by these firms. This section is written to (1) describe the research methodology of this study, (2) explain the sample selection, (3) describe the procedure used in designing the instrument and collecting the data, and (4) provide an explanation of the statistical procedures used to analyse the data.

\section{Research Design}

The study utilised exploratory and descriptive research approaches as it clarified the understanding of challenges to innovation faced by small and medium-sized enterprises in Trinidad and Tobago. Descriptive research seeks to describe the status of an identified variable, which in this case is a description of the perceptions of employees at small and medium-sized 
enterprises regarding innovation. A survey instrument in the form of a questionnaire was used for data collection.

\section{Survey Design}

A comprehensive structured survey questionnaire (Appendix 1) was carefully developed to collect quantitative data. Items 5 to 40 required responses on an interval scale which were labelled ranging from 1 ("Strong disagree) to 5 ("Strongly agree"). Items 41 to 61 were categorical questions that required 'Yes' or 'No' responses. The final items 62 to 69 required respondents to rank eight innovation barriers in terms of their importance. These innovation barriers had to ranked ranging from 1("Highest rank") to 8 ("Lowest rank"). In total, the questionnaire had four categories of questions consisting of 69 items which captured:

- $\quad$ General information about the respondent (items 1 to 4)

- $\quad$ Innovation experienced (items 5 to 29)

- Innovative environment (items 30 to 40)

- $\quad$ Innovation barriers (items 41to 69)

\section{Reliability and Validity}

The questionnaire was pilot tested for content and construct validity with a convenience sample of twenty small and medium-sized enterprises. The variables measured in the survey questionnaire were adapted from prior research completed by Talegeta (2014) and Kuratko (2014) which provided validated guidelines for investigating the challenges and barriers to innovation in small and medium sized enterprises.

\section{Sampling}

The target population for this study consisted of small and medium sized enterprises in Trinidad and Tobago that have been in active operation for a minimum of five years and have a maximum of fifty employees. A list of 500 randomly selected small and medium-sized enterprises from the business directory served as the sampling frame. A total of 350 small and medium sized enterprises participated in this study representing a $70 \%$ response rate. The participants were from a wide range of industries included food and beverage, agriculture, construction, education, retail, entertainment, transportation and clothing and textile

\section{Survey Administration}

This research was cross-sectional. Data collection was conducted over a period of fifteen weeks. Delivery and collection survey questionnaires were used. Questionnaires allowed for inexpensive and convenient data collection from the participants (Saunders, Lewis \& Thornhill, 2009). 


\section{Permission and Consent}

At the beginning of the investigation. permission was sought from the business owners and participants signed a voluntary consent form before any data was collected.

\section{Respondents}

The questionnaires were directed to the longest employed staff members of the small and medium-sized enterprises because they possessed first-hand knowledge of the business' past and current operations. Additionally, the longest serving employees were the most experienced amongst others to respond to questions on the challenges they came across during their tenure of service. It was the researcher's intention to eliminate business owners as respondents because of biases.

\section{Research Protocol}

Participant role: Participants were requested to complete the questionnaires themselves.

Time and Place: The questionnaires were distributed to participants by the researcher at location of the small and medium-sized enterprise. The respondents took approximately fifteen minutes to complete the questionnaires which were collected by the researcher subsequently.

\section{Privacy and Confidentiality}

The privacy of the respondents was maintained by assignment of a numerical code to each survey so that anonymity would be maintained by separating any identifying information from the respondents' answers. The unidentifiable raw data collected was kept confidential. Information from the surveys were digitized and retained in Microsoft Excel files but the surveys themselves were destroyed upon research completion.

\section{Statistical Data Analysis Summary Measures}

The frequency distributions of the responses to the various options in the categorical yes/no questions and for the level of the innovative environment were summarized in tables which recorded the relative percentage (\%) response frequency for each individual option. Responses to scale questions were summarized using multi-graphs, which are presented as stacked bar graphs. This gave a pictorial representation of the frequency distributions for each question on a scale and allows visual comparison between the distributions for different questions. 


\section{Discussion of Results}

\section{General Characteristics of Respondents}

Among a total of 350 respondents, most were operational staff (52\%). The second highest were sales staff (27\%). Fourteen percent of the respondents (14\%) worked in administration and seven percent $(7 \%)$ worked in other areas of their businesses. Most respondents (50\%) were employed for a period of 10 to14 years followed by thirty percent (30\%) who were employed for a period of 5 to 9 years. Ten percent (10\%) were employed for a period of 0 to 4 years and seven percent $(7 \%)$ were employed for a period of 15 to 19 years. The longest serving employees (3\%) were employed for over 20 years.

Innovation experienced by small and medium-sized enterprises in Trinidad and Tobago

Figure 1: SMEs employees perception of company's objective.

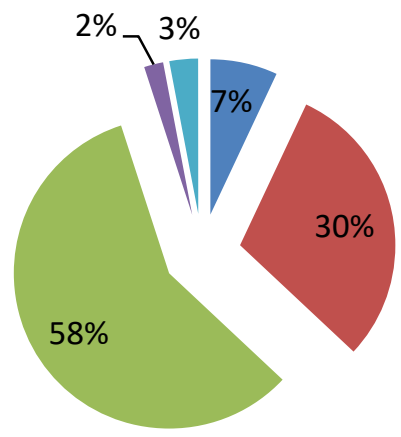

- Survival

- Growth

Profitability

- Innvoativness

Other

Figure one above demonstrates that most employees (58\%) perceived that their firms' main objective is to achieve profitability whilst the minority (2\%) perceived that their firms' main objective is innovativeness. 


\section{Figure 2: Product innovation}

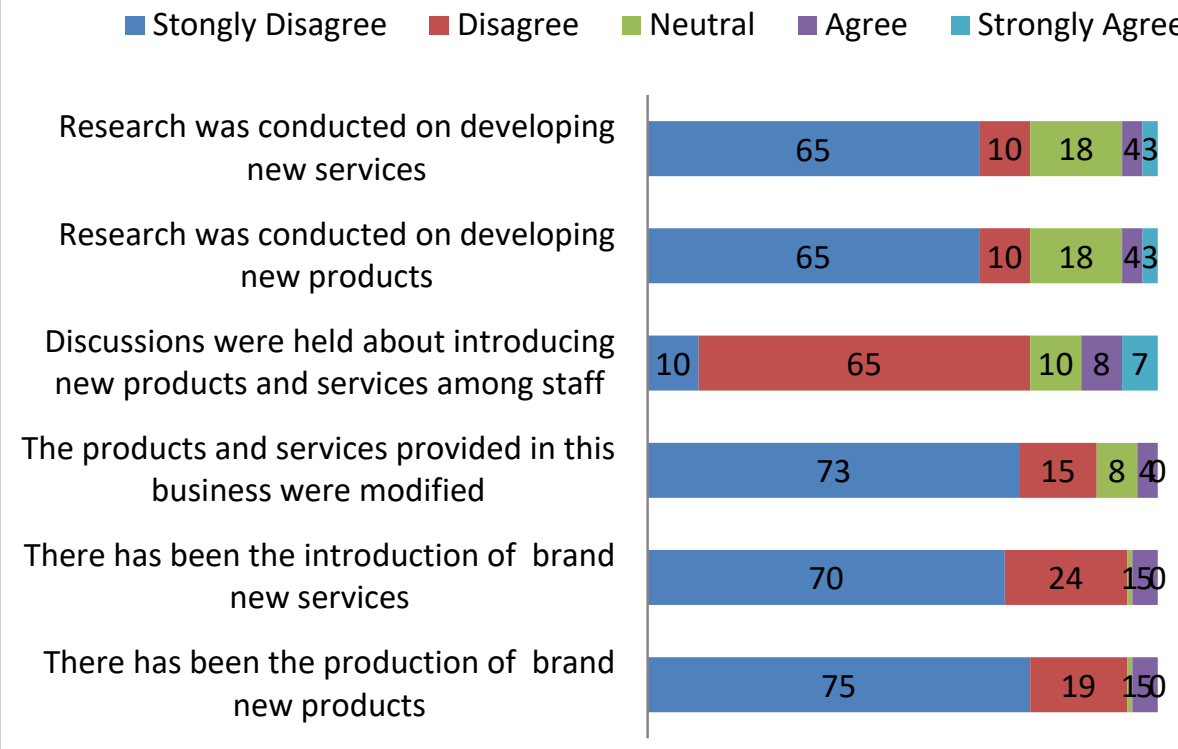

Figure two depicts six different areas of product innovation. Most of respondents strongly disagreed with five out of the six items of the scale (65$75 \%)$. Amongst the highest strong disagreements were the production of brand new services and products (75\%) and product modifications (73\%). The results indicate that there were low levels of product innovation at the small and medium-sized enterprises.

\begin{tabular}{|c|c|c|}
\hline \multicolumn{3}{|c|}{ Figure 3:Process Innovation } \\
\hline Stongly Disagree & Neutral $\quad$ Agree & Strongly Agree \\
\hline New or improved methods were... & 60 & $\begin{array}{lll}10 & 15 & 150\end{array}$ \\
\hline There was a change in the management... & 90 & 460 \\
\hline Different equipment was being utilized... & 97 & B) \\
\hline New suppliers were sourced & 65 & $13 \quad 12100$ \\
\hline There has been a change in the process... & 76 & 12840 \\
\hline There has been the implementation of a... & 88 & $10 \rrbracket$ \\
\hline There has been the implementation of a... & 90 & $8 D$ \\
\hline
\end{tabular}


Figure three demonstrates employees' perceptions of several areas of process innovation within small and medium-sized enterprises in Trinidad and Tobago. For all items on the scale, the majority of the respondents strongly disagreed with the statements on: new or improved methods for the business's general operations were discussed (60\%), there was a change in management operations (90\%), different equipment was being utilized for business operations (97\%), new supplies were sourced (65\%), there had been a change in the process to conduct day to day operations of the business (76\%), there has been the implementation of a new system for delivery(88\%)and production(90\%). There is clear evidence suggesting that there were low levels of process innovation.

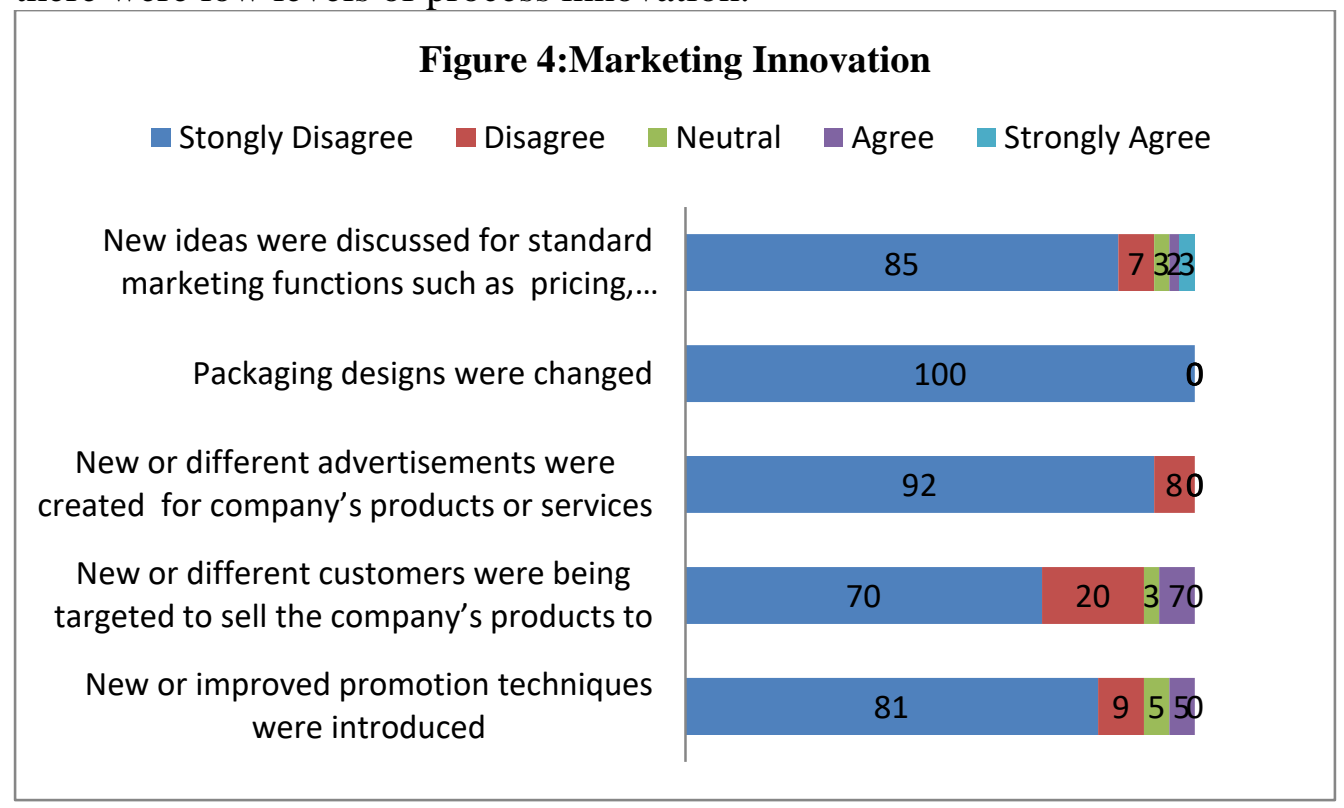

Figure four depicts the perceptions of employees on the level of marketing innovation implemented at their firms. The majority of the respondents strongly disagreed with all items of the scale ranging from $70 \%$ to $100 \%$ on strong disagreements. The results show that all $(100 \%)$ of employees agreed that packaging designs were not changed. All employees (100\%) agreed that no new or different advertisements were created for the company's products or services. Ninety percent $(90 \%)$ of the respondents disagreed with the statements; new or different customers were being targeted to sell the company's products; and new or improved promotion techniques were introduced. The results indicate that there were low levels of marketing innovation. 


\section{Figure 5: Organizational Innovation}

$\square$ Stongly Disagree $\square$ Disagree $\quad$ Neutral $\quad$ Agree $\quad$ Strongly Agree

The company hired new managers who were recruited externally

The company's organization structure has changed

The company has activities, practices and policies in place to encourage creativity...

There are proper communication systems in place for me to communicate my new.. I am constantly contributing towards the generation of new ideas within my firm

The company is constantly engaging in Research and Development activities.

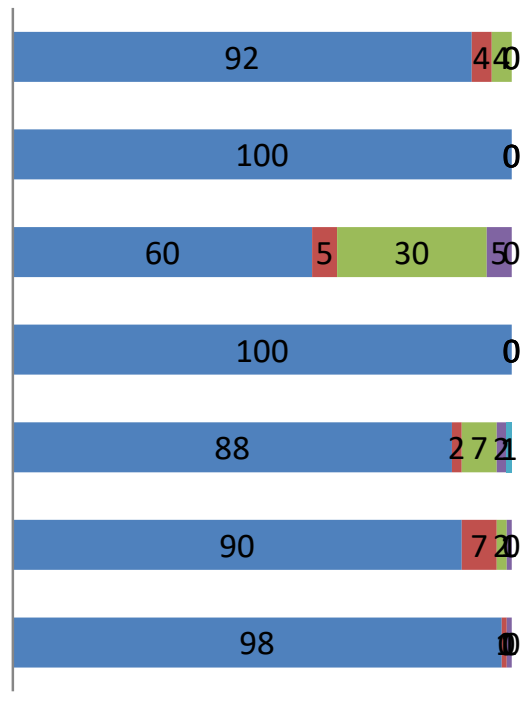

Figure five depicts employees' responses on organizational innovation. The results show that ninety-six percent (92\%) of employees strongly disagreed with the statement that their company hired new external managers. All, (100\%) of the employees agreed with the statements that their company's organizational structure has not changed and their company does not have activities, practices and policies in place to encourage creativity and innovativeness. Sixty-five percent (65\%) of the staff disagreed with the statement that their company has access to cooperating partners from external personnel, organizations and institutions to help foster innovation. Eighty-eight percent (88\%) of employees strongly disagreed with the statement that their company has proper communication systems to communicate their new ideas and views on innovative projects. Ninety percent $(90 \%)$ of employees strongly disagreed with the statement that they are contributing towards the generation of new ideas and most of respondents $(98 \%)$ of the workforce strongly disagreed with the statement that their company is constantly engaged in research and development activities. The results as depicted in figure five suggest that there were low levels of organizational innovation. 


\section{Innovative Environment}

Table 3: Level of Innovative environment

\begin{tabular}{|c|c|c|c|c|c|}
\hline $\begin{array}{c}\text { I agree that the following are } \\
\text { practiced/made available at } \\
\text { my firm: }\end{array}$ & $\begin{array}{c}\text { Strongly } \\
\text { disagree }\end{array}$ & Disagree & Neutral & Agree & $\begin{array}{c}\text { Strongly } \\
\text { Agree }\end{array}$ \\
\hline Brainstorming sessions & 98 & 2 & 0 & 0 & 0 \\
\hline Innovation Recognition Days & 100 & 0 & 0 & 0 & 0 \\
\hline $\begin{array}{c}\text { Training and Development on } \\
\text { Creativity }\end{array}$ & 87 & 10 & 0 & 3 & 0 \\
\hline Employee Socializing Events & 100 & 0 & 0 & 0 & 0 \\
\hline Gym and Sporting area & 100 & 0 & 0 & 0 & 0 \\
\hline In Company Library & 100 & 0 & 0 & 0 & 0 \\
\hline Cross Functional teams & 82 & 2 & 5 & 1 & 0 \\
\hline Job Rotation & 86 & 6 & 4 & 4 & 0 \\
\hline $\begin{array}{c}\text { Employee Flexibility in Time } \\
\text { and Work methods }\end{array}$ & 80 & 10 & 5 & 5 & 0 \\
\hline $\begin{array}{c}\text { Open communication for } \\
\text { levels within the firm }\end{array}$ & 60 & 20 & 5 & 10 & 5 \\
\hline Shared decision making & 100 & 0 & 0 & 0 & 0 \\
\hline
\end{tabular}

As depicted in table three, most employees were of the view that their businesses did not provide an innovative environment. 100\% of employees were of view that 'shared decision making', 'socializing events' and 'innovation recognition days' were not practiced by their firms and 'a company library' and 'gym and sporting area' were not made available at their firms. Eighty percent (80\%) of employees stated that their firms do not practice employee flexibility in time and work methods whilst eighty-six percent (86\%) of staff stated that job rotation is not often practiced in their firms. Eighty-two percent (82\%) of staff agreed that cross functional teams were occasionally used at their firms. Most of the respondents (87\%) perceived that their firms do not frequently engage in training and development for creativity and that their firms lack the use of brainstorming sessions (98\%). The results indicate that there were low levels of an innovative environment at the small and medium-sized enterprises in Trinidad and Tobago.

\section{Innovation Barriers}

Table 4: Lack of Knowledge Barrier

\begin{tabular}{|c|c|c|}
\hline Do you think the following has negatively impacted & \multicolumn{2}{|c|}{ \% Responses } \\
\cline { 2 - 3 } your firm's ability to be innovative? & No & Yes \\
\hline Lack of information on technology & 15 & 85 \\
\hline Lack of information on markets & 20 & 80 \\
\hline Inadequate Research and Development & 8 & 92 \\
\hline
\end{tabular}


Table four depicts forms of innovation barriers associated with a lack of knowledge within small and medium-sized enterprises in Trinidad and Tobago. For all items in the scale, most employees perceived that the lack of information on technology (85\%), markets (80\%) and inadequate research and development (92\%) prevented their firms from being innovative. The results indicate that inadequate research and development is the most frequent contributing factor (92\%) to knowledge barriers of innovation at their businesses.

Table 5: Lack of Co-operation and Finance Barrier

\begin{tabular}{|c|c|c|}
\hline Do you think the following has negatively impacted & \multicolumn{2}{|c|}{ \% Responses } \\
\cline { 2 - 3 } your firm's ability to be innovative? & No & Yes \\
\hline Lack of innovation partners & 10 & 90 \\
\hline Insufficient funds to carry out innovative projects & 5 & 95 \\
\hline Insufficient funds to support and encourage creativity & 5 & 95 \\
\hline
\end{tabular}

The results shown in table five indicate that employees believe that a lack of finance and co-operation partners have negatively impacted their firms' ability to innovative. Ninety percent (90\%) of employees saw that the lack of innovation partners hampered their firms' innovativeness. Ninetyfive percent (95\%) of employees saw that insufficient funds 'to carry out innovative projects' and 'to support and encourage creativity' were impairments to their firms' innovativeness.

Table 6: Lack of Skilled Personnel Innovation Barrier

\begin{tabular}{|c|c|c|}
\hline Do you think the following has negatively impacted & \multicolumn{2}{|c|}{ \% Responses } \\
\cline { 2 - 3 } your firm's ability to be innovative? & No & Yes \\
\hline $\begin{array}{c}\text { Insufficient skilled, qualified and competent } \\
\text { personnel to foster its creativity and innovativeness }\end{array}$ & 0 & 80 \\
\hline $\begin{array}{c}\text { Incompetent personnel to carry out innovative } \\
\text { projects. }\end{array}$ & 23 & 87 \\
\hline
\end{tabular}

Table six depicts that all (100\%) employees agreed that their firms' innovativeness was negatively impacted because of the lack of skilled, qualified and competent personnel to foster creativity and innovativeness whilst the majority (87\%) believed that the presence of incompetent personnel to carry out innovative projects was an innovation barrier.

Table 7: Lack of Reward and Recognition Innovation Barrier

\begin{tabular}{|c|c|c|}
\hline Do you think the following has negatively impacted & \multicolumn{2}{|c|}{ \% Responses } \\
\cline { 2 - 3 } your firm's ability to be innovative? & No & 100 \\
\hline $\begin{array}{c}\text { New and creative ideas as well as innovative projects } \\
\text { go unrecognized and unrewarded. }\end{array}$ & 0 & 100 \\
\hline $\begin{array}{c}\text { Failed innovative projects are discouraged to be } \\
\text { retried for success not punished. }\end{array}$ & 0 & 100 \\
\hline $\begin{array}{c}\text { Employees whose attempts to innovative projects } \\
\text { have failed are punished. }\end{array}$ & 0 & \\
\hline
\end{tabular}


Table seven displays that all (100\%) of employees perceived that a lack of reward and recognition prevented their firms' ability to innovate.

Table 8: Market Innovation Barrier

\begin{tabular}{|c|c|c|}
\hline Do you think the following has negatively impacted & \multicolumn{2}{|c|}{ \% Responses } \\
\cline { 2 - 3 } your firm's ability to be innovative? & No & Yes \\
\hline $\begin{array}{c}\text { Threat of competitors' reaction to your firm's } \\
\text { innovation }\end{array}$ & 15 & 85 \\
\hline $\begin{array}{c}\text { Uncertainty on customers' preference to purchasing } \\
\text { your firm's new or improved product or service }\end{array}$ & 20 & 80 \\
\hline
\end{tabular}

The results indicate that the majority of employees saw market factors were barriers to their firms' innovation as eighty-five percent (85\%) agreed that uncertainties on customers' preferences to purchasing their firms new or improved product or service and eight percent (80\%) agreed that the threat of competitors' reaction to their firms' innovativeness prevented their firms from being innovative as depicted in table eight.

Table 9: Lack of Organisation Culture Innovation Barrier

\begin{tabular}{|c|c|c|}
\hline Do you think the following has negatively impacted & \multicolumn{2}{|c|}{ \% Responses } \\
\cline { 2 - 3 } your firm's ability to be innovative? & No & Yes \\
\hline Employees are resistant to change in the work place & 15 & 85 \\
\hline Management are risk aversive & 0 & 100 \\
\hline Lack of management support & 0 & 100 \\
\hline Lack of strategic planning & 33 & 67 \\
\hline
\end{tabular}

Table nine shows employees' views on their organizations' cultural elements and its impact on their firms' ability to innovate. The results indicate that the lack of management's support $(100 \%)$ and management risk aversion (100\%) were the most frequent factors that prevented their firms' ability to innovate. To a lesser extent, the lack of strategic planning (67\%) was perceived as a factor that prevented their firms' ability to innovate.

Table 10: Legal Innovation Barrier

\begin{tabular}{|c|c|c|}
\hline Do you think the following has negatively impacted & \multicolumn{2}{|c|}{ \% Responses } \\
\cline { 2 - 3 } your firm's ability to be innovative? & No & Yes \\
\hline Too many strict regulations set by Government & 30 & 70 \\
\hline $\begin{array}{c}\text { Little or no incentives by Government to encourage } \\
\text { business innovation }\end{array}$ & 15 & 85 \\
\hline $\begin{array}{c}\text { Threat of intellectual property theft } \\
\text { Tyy }\end{array}$ & 23 & 77 \\
\hline
\end{tabular}

Table ten depicts employees' responses on legal barriers that prevented their firms' innovativeness. Seventy-seven percent (77\%) of the respondents perceived that the threat of intellectual property theft hampered their firms' innovativeness. Eighty-five percent of the respondents (85\%) agreed that little or no incentives by the government to encourage business innovation prevented their firms' ability to innovate. Seventy percent of the 
respondents (70\%) stated that too many strict regulations set by the government prevented their firms’ ability to innovate.

Table 11: Ranking of Barriers to innovation

\begin{tabular}{|c|c|c|c|c|c|c|c|c|}
\hline Innovation Barrier & $\begin{array}{c}\text { Highest } \\
\text { Rank } \\
1\end{array}$ & 2 & 3 & 4 & 5 & 6 & 7 & $\begin{array}{c}\text { Lowest } \\
\text { Rank } \\
8\end{array}$ \\
\hline Lack of Knowledge & 5 & 10 & 1 & 4 & 15 & 20 & 5 & 40 \\
\hline Lack of Finance & 15 & 15 & 40 & 20 & 2 & 3 & 4 & 1 \\
\hline Lack of Co-operation & 3 & 2 & 5 & 8 & 2 & 8 & 12 & 60 \\
\hline Lack of Skilled Personnel & 5 & 5 & 5 & 50 & 5 & 18 & 6 & 6 \\
\hline $\begin{array}{c}\text { Lack of Reward and } \\
\text { Recognition }\end{array}$ & 10 & 60 & 8 & 2 & 7 & 3 & 5 & 5 \\
\hline Market Barrier & 5 & 10 & 3 & 7 & 10 & 5 & 55 & 5 \\
\hline Legal Barrier & 2 & 1 & 3 & 3 & 3 & 1 & 2 & 85 \\
\hline $\begin{array}{c}\text { Organizational Culture- } \\
\text { Barrier }\end{array}$ & 55 & 24 & 6 & 5 & 2 & 6 & 1 & 1 \\
\hline
\end{tabular}

The results indicate that the top three barriers to innovation experienced by small and medium-sized businesses in Trinidad and Tobago organizational culture, lack of reward and recognition and lack of finance as depicted in table eleven. The lowest ranked barrier to innovation was legal barriers.

\section{Conclusion}

Innovation activities are important elements of firms' overall strategies (Holzl \& Janger, 2011). Based on the results, it was found that although there were profitability goals set by the small and medium-sized enterprises in Trinidad and Tobago, there was a lack of strategies developed for creating an innovative environment within these businesses.

The data suggests that there were limited management efforts to implement strategies for encouraging innovativeness and creativeness within their organizations. The results indicate that there were low levels of product innovation, process innovation, marketing innovation and organizational innovation in small and medium-sized enterprises in Trinidad and Tobago.

Talegeta (2014) stated that an organization's innovative activities contribute greatly to its competitiveness and success. The results indicate that small and medium-sized enterprises in Trinidad and Tobago are exposed to several barriers to innovation. It can be concluded from the data that the main barriers which negatively impacted these firms in descending order of impact are as follows: organizational culture, lack of reward and recognition, lack of finance, lack of skilled personnel, lack of knowledge, lack of cooperation, market barriers and legal barriers. All these barriers which are experienced by these firms confirm to previous research done by Silva et al. 
(2007); Lim and Shyamala (2007); Mohen and Roller (2005); and Baldwin and Lin (2002).

The theory set out by Tidd et al. (2007) stated that innovative firms that used innovative processes within their organizations had improved and differentiated their products and services and outperformed their competitors in regards to market share, profitability and growth. It was concluded from this study that the barriers hindering these small and medium-sized firms' innovation can negatively impact their performance by leading to inefficiencies in their operations in the form of the provision of outdated products and services, outdated policies and procedures, decrease in their firms' competitiveness, decrease in sales revenue and profitability and loss of market share. These findings are in accordance to the contribution made by Vincent, Bharadwaj and Challagalla (2004) who stated that innovation barriers are negatively related to superior performance.

\section{References:}

1. Assink, M. (2006). Inhibitors of Disruptive Innovation Capability: A Conceptual Model. European Journal of Innovation Management, 5(9), 215-233.

2. Babu, R., Krishna, M., \& Swathi, A. (2013). Role of Creativity and Innovation in Entrepreneurship. Innovative Journal of Business and Management, 2(5), 112-115.

3. Bailey, H., Pacheco, M., Carillo, M., Pememberton, G., \& Ghany, G. (2015). Global Entrepreneurship Monitor Trinidad and Tobago 2014 Report. London Business School. London: Global Entrepreneurship Research Association.

4. Baldwin, J., \& Lin, Z. (2002). Impediments to Advanced Technology Adoption for Canadian Manufacturers. Research Policy, 31(1), 1-18.

5. Bernard, H. (1988). Research Methods in Cultural Anthropology. Newbury Park, California: Sage Publication Inc.

6. Bessant, J., \& Tidd, J. (2009). Managing Innovation: Integrating Technological, Market and Organisational Change. Chichester: Wiley.

7. Bessant, J., Pavitt, K., \& Tidd, J. (2001). Managing Innovation: Integrating Technological Market and Organisational Change. Chichester: Wiley.

8. Bharadwaj, S., Vincent, L., \& Challagalla, G. (2004). Does Innovation Mediate Firm Performanace?: A Meta-Analysis of Determinants and Consequences of Organisational Innovation. Atlanta: Georgia Institute of Technology.

9. Chaminade, C., Lundvall, B., Joseph, K., \& Vang, J. (2009). Innnovation Systems and Developing Countires: An Introduction. 
Lund University. Centre for Innovation,Research and Competence in the Learning Economy.

10. Chand, S. (2015). Importance of Innovation and Creativity for Success of an Organisation. Retrieved March 2017, from Your Article

Library:

http://www.yourarticlelibrary.com/organization/importance-ofinnovation-and-creativity-for-success-of-an-organisation/21142/

11. Covin, J., \& Slevin, D. (1989). Strategic Management of Small Firms in Hostile and Benign Environments. Strategic Management Journal, 10(1), 75-87.

12. Covin, J., Dess, G., \& Lumpkin, G. (1997). Entrepreneurial Strategy Making and Firm Performance: Tests of Contingency and Configurational Models. Strategic Management Journal, 18(9), 677695.

13. Creswell, J. (2013). Design Qualitative,Quantitative and Mixed Methods Approaches (2 ed.). California: Sage Publications Inc.

14. Damanpour, F. (1991). Organizational Innovation: A Meta-Analysis of Effects of Determinants and Moderators, Academy of Management Journal, 34(2), 555-590.

15. DeAngelis, S. (2012, November 26). Fostering an Innovative Environment, Part 1. Retrieved November 2015, from Enterra Solutions: http://www.enterrasolutions.com/2012/11/fostering-aninnovative-environment-part-1.html

16. Demirbas, D. (2011). How do Entrepreneurs Perceive Barriers to Innovation? Empirical Evidence from Turkish SMEs. 14th International Business Research Conference. Victoria: World Business Institute Australia.

17. Deshati, E. (2016). Business Strategies of SMEs, Innovation Types and Factors Influencing their Innovation: Albanian Case. International Journal of Economics \& Management Sciences, 5(3).

18. Dess, G., \& Lumpkin, G. (2001). Linking Two Dimensions of Entrepreneurial Orientation to Firm Manufacturers. Research Policy, 31, 1-18.

19. Drucker, P. (1985). Innovation and Entrepreneurship. Basingstoke: Macmillan.

20. Drucker, P. (1992). The Big Power of Little Ideas Economic Review. Economic Review, 49, 1431-1450.

21. Eurostat. (2006, August 30). The Communication Innovation Survey 2006. Retrieved 2016, from Europa: http://ec.europa.eu/eurostat/documents/203647/203701/CIS_Survey_ form_2006.pdf/3e01428c-af1d-4512-9c6f-46f7616c85c9 
22. Fitjar, R. D., \& Rodríguez-Pose, A. (2013). Firm Collaboration and Modes of Innovation in Norway. Research Policy, 42, 128-138.

23. Geroski, P., Machin, S., \& Van Reenen, J. (1993). The Profitability of Innovating Firms. RAND Journal of Economics, 24(2), 198-211.

24. Han, J., Kim, N., \& Srivastava, R. (1998). Market Orientation and Organizational Performance: Is Innovation a Missing Link? Journal of Marketing, 62, 30-45.

25. Hattori, R., \& Wycoff, J. (2002). Innovation DNA: A Good Idea is Not Enough. It has to Create Value. Training and Development, 56(2), 25-39.

26. Hoelzl, W., \& Janger, J. (2011). Innovation Barriers Across Firm Types and Countries. DIME Final Conference. Austria: Austrian Economic Research Institute. Retrieved from http://final.dimeeu.org/files/hoelzl_janger_E5.pdf

27. Horth, D., \& Buchner, D. (2014). Innovation Leadership How to use Innovation to Lead Effectively, Work Collaboratively, and Drive Results. Centre for Creative Leadership.

28. Jaramillo, H., Lugones, G., \& Salazar, M. (2001). Standardisation of Indicators of Technological Innovation in Latin American and Caribbean Countries. Colombia: Iberoamerican Network of Science and Technology.

29. Kim, W., \& Maubourgne, R. (2005). Blue Ocean Strategy. Boston, Massachusetts: Harvard Business School Press.

30. Kuratko, D. (2014). Entrepreneurship: Theory, Process, Practice (9th ed.). Mason, Ohio: South Western Cengage Learning.

31. Lewis, J. (1993). Developing the Mixed Economy of Care: Emerging Issues for Voluntary Organisations. Journal of Social Policy, 22(2), 173-92.

32. Lim, S., \& Shyamala, N. (2007). Obstacles to Innovation: Evidence from Malaysian Manufacturing Firms. Malaya: University of Malaya.

33. Markatou, M., \& Stournaras, Y. (2013). International Alliance Portfolios and Innovation: A Proposal for an Analytical Model Based on Bibliographic and Bibliometric Research. Journal of Global Business and Technology, 9(2), 112-120.

34. Martín-de Castro, M., Delgado-Verde, J., Navas-López, J., \& CruzGonzález. (2013). The Moderating Role of Innovation Culture in the Relationship between Knowledge Assets and Product Innovation. Technological Forecasting and Social Change, 80(2), 351-363.

35. Mbizi, R., Thondhlana, A., \& Kakava, N. (2013). Innovation in SMEs: A review of its Role to Organisational Performance and SMEs 
Operations Sustainability. Institute of Interdisciplinary Business Research, 4(11), 50-62.

36. Miles, M., \& Huberman, M. (1994). Qualitative Analysis: An Expanded Sourcebook, (2nd ed.). Thousand Oaks, California: Sage Publication Inc.

37. Mohnen, P., \& Roller, L. (2005). Complementarities in Innovation Policy. European Economic Review, 49(6), 1431-1450.

38. OECD, \& Eurostat. (2005). Oslo Manual: Guidelines for Collecting and Interpreting Innovation. Organisation for Economic Cooperation and Development. France: OECD Publishing.

39. Robson, C. (2002). Research Methods for Business Students. Essex: Pearson Education Limited.

40. Saunders, M., Lewis, P., \& Thornhill, A. (2009). Research Methods for Business Students (5th ed.). Edinburgh Gate, Harlow, England: Pearson Education Limited.

41. Schumpeter, J. (1934, January). The Theory of Economic Development. Retrieved from Harvard Business Press: http://www.hup.harvard.edu/catalog.php?isbn=9780674879904

42. Schwab, K. (2013). The Global Competitiveness Report 2013-2014. World Economic Forum. Boston: Harvard Business School.

43. Serrat, O. (2009). Harnessing Creativity and Innovation in the Workplace, Knowledge Solutions. Asian Development Bank.

44. Shepherd, D., \& Wiklund, J. (2005). Entrepreneurial orientation and small business performance: a configurational approach. Journal of Business Venturing, 20(1), 71-91.

45. Silva, M., Leitao, J., \& Raposo, M. (2007). Barriers to Innovation Faced by Manufacturing Firms in Portugal: How to overcome it? 10(1), 75-87.

46. Sousa, D. (2006). The Sustainable Innovation Engine. 36(4), 57-72.

47. Spinlelli, S., \& Timmons, J. (2004). New Venture Creation (6th ed.). Boston: Irwin.

48. Talegata, S. (2014). Innovation and Barriers to Innovation: Small and Medium Enterprises in Addis Ababa. Journal of Small Business and Entrepreneurship Development, 2(1), 83-106.

49. Tidd, J., Bessant, J., \& Pavitt, K. (2007). Management of innovation The Introduction of Technological, Market and Organizational Changes. John Wiley and Sons.

50. Uhrbach, M. (2005). Innovation in the Canadian Manufacturing Sector. Canada: Business Special Surveys and Technology Statistics Division.

51. UNESCO. (2005). The Measurement of Scientific and Technological Activities. ECD and Eurostat Organisation for Economic Co- 
operation and Developmental Statistical Office of the European Communities. France: OECD Publications.

52. Woolthuis, R. (2005). A System Failure Framework for Innovation Policy Design. Technovation, 25(1), 609-619.

53. Zemplinerova, A. (2010). Innovation Activity of Companies and Competition. Political Economy, 58(6), 747-760.

\section{Appendix 1 Survey Questionnaire}

Dear respondent,

This questionnaire is designed to acquire data for an investigation into the main barriers to innovation encountered by small and medium sized enterprises in Trinidad and Tobago. Your response is vital to the outcome of the study and you are requested to completely and objectively answer all questions. Your cooperation to respond genuinely is very important to this study. I would promise that all information you provide would be strictly confidential.

Thank you in advance for your indispensable cooperation to spare invaluable time and energy to complete these questionnaires.

Respectfully, Dr. Priscilla Bahaw

The University of the West Indies

Please answer the following questions by ticking the most appropriate box:

\section{General information:}

1. What is your position in this firm?

$\square$ Operational $\quad \square$ Sales $\quad \square$ Administrative $\quad \square \quad$ Other

2. How long have you been employed by this firm?

$\square$ 0-4 years $\square$ 5-9 years $\square$ 10-14 years $\square$ 15-19 years $\square$ over 20 years

3. What do you think is this firm's main objective? (more than 1 option can be chosen)

$\square$ Survival $\quad \square$ Growth $\quad \square$ Profitability $\quad \square$ Innovativeness

$\square$ Other

4. When last has the company introduced something new?

$\square$ within the last 5 years $\quad \square$ within the last 6-10 years $\quad \square$ within the last $11-15$ years

$\square$ within the last $16-20$ years $\quad \square$ over 20 years 


\section{Innovation Experienced:}

Please indicate your level of agreement with the statements below, using a scale of 1 (strongly disagree) to 5 (strongly agree):

\begin{tabular}{|c|c|c|c|c|c|c|}
\hline \multicolumn{2}{|r|}{$\begin{array}{c}\text { Lead Statement: During the past five years of working in this } \\
\text { business.... }\end{array}$} & $\begin{array}{l}\text { Strongly } \\
\text { Disagree }\end{array}$ & & & & $\begin{array}{l}\text { Strongl } \\
\text { y Agree }\end{array}$ \\
\hline \multirow{2}{*}{\multicolumn{2}{|c|}{ Product Innovation }} & 1 & 2 & 3 & 4 & 5 \\
\hline & & & & & & \\
\hline 5 & There has been the production of brand new products & & & & & \\
\hline 6 & There has been the introduction of brand new services & & & & & \\
\hline 7 & $\begin{array}{c}\text { The products and services provided in this business were } \\
\text { modified }\end{array}$ & & & & & \\
\hline 8 & $\begin{array}{c}\text { Discussions were held about introducing new products and } \\
\text { services among staff }\end{array}$ & & & & & \\
\hline 9 & Research was conducted on developing new products & & & & & \\
\hline \multirow[t]{2}{*}{10} & Research was conducted on developing new services & & & & & \\
\hline & \begin{tabular}{|l} 
Process Innovation \\
\end{tabular} & & & & & \\
\hline 11 & $\begin{array}{c}\text { There has been the implementation of a new system for } \\
\text { production }\end{array}$ & & & & & \\
\hline 12 & There has been the implementation of a new system for delivery & & & & & \\
\hline 13 & $\begin{array}{l}\text { There has been a change in the process to conduct the day to } \\
\text { day operations of the business }\end{array}$ & & & & & \\
\hline 14 & New suppliers were sourced & & & & & \\
\hline 15 & Different equipment was being utilized for business operations & & & & & \\
\hline 16 & There was a change in the management operations & & & & & \\
\hline \multirow[t]{2}{*}{17} & $\begin{array}{l}\text { New or improved methods were discussed for the business } \\
\text { general operations }\end{array}$ & & & & & \\
\hline & Marketing Innovation & & & & & \\
\hline 18 & New or improved promotion techniques were introduced & & & & & \\
\hline 19 & $\begin{array}{l}\text { New or different customers were being targeted to sell the } \\
\text { company's products to }\end{array}$ & & & & & \\
\hline 20 & $\begin{array}{l}\text { New or different advertisements were created for company’s } \\
\text { products or services }\end{array}$ & & & & & \\
\hline 21 & Packaging designs were changed & & & & & \\
\hline \multirow[t]{2}{*}{22} & $\begin{array}{l}\text { New ideas were discussed for standard marketing functions } \\
\text { such as pricing, packaging and promotion }\end{array}$ & & & & & \\
\hline & Organizational Innovation & & & & & \\
\hline 23 & $\begin{array}{l}\text { The company is constantly engaging in Research and } \\
\text { Development activities. }\end{array}$ & & & & & \\
\hline 24 & $\begin{array}{l}\text { I am constantly contributing towards the generation of new } \\
\text { ideas within this firm }\end{array}$ & & & & & \\
\hline 25 & $\begin{array}{l}\text { There are proper communication systems in place for me to } \\
\text { communicate my new ideas and views on innovative projects }\end{array}$ & & & & & \\
\hline 26 & $\begin{array}{l}\text { The company has activities, practices and policies in place to } \\
\text { encourage creativity and innovativeness. }\end{array}$ & & & & & \\
\hline 27 & $\begin{array}{l}\text { The company has access to cooperating partners from external } \\
\text { personnel, organizations and institutions to help foster its } \\
\text { innovativeness. }\end{array}$ & & & & & \\
\hline 28 & The company’s organization structure has changed & & & & & \\
\hline 29 & $\begin{array}{c}\text { The company hired new managers who were recruited } \\
\text { externally }\end{array}$ & & & & & \\
\hline
\end{tabular}


Innovative Environment

Please rate your answer using a scale of 1 (Strongly Disagree) to 5 (Strongly Agree)

\begin{tabular}{|c|c|c|c|c|c|c|}
\hline \multirow{2}{*}{\multicolumn{2}{|c|}{$\begin{array}{l}\text { Please rate your agreement if your firm practice the } \\
\text { following? }\end{array}$}} & \multirow{2}{*}{$\frac{\text { SD }}{1}$} & \multirow[b]{2}{*}{2} & \multirow[b]{2}{*}{3} & \multirow[b]{2}{*}{4} & \multirow{2}{*}{$\frac{\text { SA }}{5}$} \\
\hline & & & & & & \\
\hline 30 & Brainstorming sessions & & & & & \\
\hline 31 & Innovation Recognition Days & & & & & \\
\hline 32 & Training and Development on Creativity & & & & & \\
\hline 33 & Employee Socializing Events & & & & & \\
\hline 34 & Gym and Sporting area & & & & & \\
\hline 35 & In Company Library & & & & & \\
\hline 36 & Cross Functional teams & & & & & \\
\hline 37 & Job Rotation & & & & & \\
\hline 38 & $\begin{array}{c}\text { Employee Flexibility in Time and Work } \\
\text { methods }\end{array}$ & & & & & \\
\hline 39 & $\begin{array}{l}\text { Open communication for levels within the } \\
\text { firm }\end{array}$ & & & & & \\
\hline 40 & Shared decision making & & & & & \\
\hline
\end{tabular}

\section{Innovation Barriers}

Please respond Yes or No to the following if you consider these to be factors that prevented your firm from being innovative during the last five years.

\begin{tabular}{|c|c|c|c|}
\hline & Subject Area & Yes & No \\
\hline & Lack of Knowledge Barrier & & \\
\hline 41 & Lack of information on technology & & \\
\hline 42 & Lack of information on markets & & \\
\hline \multirow{2}{*}{43} & Inadequate Research and Development & & \\
\hline & Lack of Co-operation Barrier & & \\
\hline \multirow[t]{2}{*}{44} & Lack of innovation partners & & \\
\hline & Lack of Finance Barrier & & \\
\hline 45 & Insufficient funds to carry out innovative projects. & & \\
\hline 46 & In sufficient funds to support and encourage creativity & & \\
\hline \multirow[t]{2}{*}{47} & Renewing mean investing in expensive capital & & \\
\hline & Lack of skilled personnel Barrier & & \\
\hline 48 & $\begin{array}{c}\text { Insufficient skilled, qualified and competent personnel to foster its } \\
\text { creativity and innovativeness }\end{array}$ & & \\
\hline \multirow[t]{2}{*}{49} & Incompetent personnel to carry out innovative projects. & & \\
\hline & Lack of Reward and Recognition Barrier & & \\
\hline 50 & $\begin{array}{l}\text { New and creative ideas as well as innovative projects go unrecognized } \\
\text { and unrewarded. }\end{array}$ & & \\
\hline 51 & $\begin{array}{l}\text { Failed innovative projects are discouraged to be retried for success not } \\
\text { punished. }\end{array}$ & & \\
\hline \multirow[t]{2}{*}{52} & $\begin{array}{l}\text { Employees whose attempts to innovative projects have failed are } \\
\text { punished. }\end{array}$ & & \\
\hline & Market Barrier & & \\
\hline 53 & Threat of competitors reaction to your firm's innovation & & \\
\hline 54 & Uncertainty on customers preference to purchasing your firm's new or & & \\
\hline
\end{tabular}




\begin{tabular}{|l|c|l|l|}
\hline & improved product or service & & \\
\hline & Organizational Culture Barrier & & \\
\hline 55 & Management are risk aversive & & \\
\hline 56 & Lack of management support & & \\
\hline 57 & Lack of strategic planning & & \\
\hline 58 & Legal Barrier & & \\
\hline & Too many strict regulations set by Government & & \\
\hline 59 & Threat of intellectual property theft & & \\
\hline 60 & Little or no incentives by Government to encourage business innovation & & \\
\hline 61 & &
\end{tabular}

Please rank from highest to lowest, the extent to which these factors are hindering your company from being innovative. Indicate by using the rank 1-8 where 1 is the highest ranked position and 8 is the lowest in the ranking.

\begin{tabular}{|c|c|c|}
\hline 62 & Lack of Knowledge & \\
\hline 63 & Lack of Finance & \\
\hline 64 & Lack of Co-operation & \\
\hline 65 & Lack of Reward and Recognition & \\
\hline 66 & Market Barrier & \\
\hline 67 & Legal Barrier & \\
\hline 68 & Organizational Culture Barrier & \\
\hline 69 & Lack of Reward and Recognition & \\
\hline
\end{tabular}

Thank you End of Survey 